\title{
ALMOST CONVEX FUNCTIONS ON LOCALLY COMPACT ABELIAN GROUPS
}

\author{
WITOLD JARCZYK AND MIKLÓS LACZKOVICH
}

Abstract. Let $G$ be a locally compact Abelian group divisible by 2 . We prove that every almost convex function on $G$ equals a convex function a.e.

Mathematics subject classification (2010): 22D99.

Keywords and phrases: Almost convex functions, loccaly compact Abelian group.

\section{REFERENCES}

[1] E. Hewitt AND K. A. Ross, Abstract Harmonic Analysis, Vol. I. Springer, 1979.

[2] M. KucZMA, Almost convex functions, Colloq. Math. 21 (1970), 279-284.

[3] M. KuCZMA, An introduction to the theory of functional equations and inequalities. Cauchy's equation and Jensen's inequality, Państwowe Wydawnictwo Naukowe, Uniwersytet Śląski, Warszawa-KrakówKatowice, 1985.

[4] W. RUDIN, Fourier Analysis on Groups, Reprint of the 1962 original. John Wiley \& Sons, 1990. 